Proc. Indian Acad. Sci. (Chem. Sci.), Vol. 107, No. 2; April 1995, pp. 101-108.

(C) Printed in India.

\title{
Coordinating behaviour of a tridentate Schiff-base in its normal and hemi-acetal forms towards some $3 d$-metal ions
}

\author{
PARITI S S J SASTRY and T R RAO* \\ Department of Chemistry, Faculty of Science, Banaras Hindu University, \\ Varanasi 221005 , India \\ MS received 5 September 1994; revised 4 March 1995

\begin{abstract}
Metal complexes of the empirical formula [M(Hpbzgh $\left.)_{2}\right]$, where $\mathrm{H}_{2}$ pbzgh = pyridoxal $\mathbf{N}$-benzoylglycyl hydrazone and $\mathbf{M}=\mathbf{M n}$ (II), $\mathrm{Co}$ (II), $\mathrm{Ni}$ (II), $\mathrm{Cu}(\mathrm{II}), \mathrm{Zn}$ (II), have been synthesized and their structures studied by electronic, IR, ${ }^{1} \mathrm{H}$ and ${ }^{13} \mathrm{C}$ NMR spectra. IR and NMR spectral data indicate uninegative tridentate coordinated ligand bonding through hydrazidic carbonyl/imidolic oxygen, azomethine nitrogen and phenolate oxygen with its pyridoxal moiety in hemi-acetal as well as normal forms. Magnetic and electronic spectral data suggest distorted octahedral geometry for the $\mathrm{Mn}(\mathrm{II}), \mathrm{Co}(\mathrm{II}), \mathrm{Ni}(\mathrm{II})$ and $\mathrm{Cu}(\mathrm{II})$ complexes.
\end{abstract}

Keywords. Pyridoxal $N$-benzoylglycyl hydrazone complexes; $3 d$-metal complexes; unsymmetric Schiff-base complexes.

\section{Introduction}

Schiff-bases derived from pyridoxal and amino acids became prominent recently since metabolic reactions of amino acids involving transamination, racemization and decarboxylation are known to proceed through Schiff bases derived from pyridoxal and amino acids or their analogues (Shanbag and Martell 1980). Schiff-bases and related analogues are also known for their catalytic activity in racemization reactions (Dunathan 1963, 1971) of peptide synthesis (Kovaes 1980), nutrition and formation of biogenic amines (Metzler et al 1980, Casella et al 1982; Friedmann and Gumbamann 1984) geochronology and geothermometry (Bada and Scholeder 1975; Smith et al 1978). Further, the stereoelectronic requirement of an amino acid bond cleavage enables pyridoxal-dependent enzymes to achieve reaction specificity and to enhance the reaction rate by appropriate conformational orientation of the bond to be cleaved (or formed) (Metzler et al 1980; Casella et al 1982). Hence, in continuation of our studies on metal complexes of Schiff-bases (Rao et al 1985, 1989, 1992, 1994; Rao and Singh 1989, 1991; Rao and Srivastava 1992) and with a view to investigating the ligational behaviour of $\mathrm{H}_{2}$ pbzgh towards $3 \mathrm{~d}$-metal ions we have undertaken the synthetic and structural studies of $\mathrm{Mn}(\mathrm{II}), \mathrm{Co}(\mathrm{II}), \mathrm{Ni}(\mathrm{II}), \mathrm{Cu}$ (II) and $\mathrm{Zn}$ (II) complexes of the Schiff-base derived from pyridoxal and $\mathrm{N}$-benzoylglycine hydrazide $\left(\mathrm{H}_{2} \mathrm{pbzgh}\right)$ (figure 1) and the results are discussed here.

\footnotetext{
* For correspondence
} 


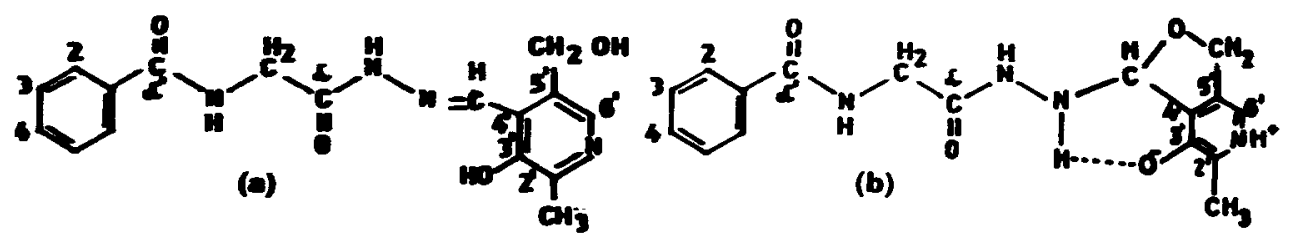

Figure 1. Proposed structure of $\mathrm{H}_{2}$ pbzgh; (a) normal form (b) hemi-acetal form.

True 1. IR spoctral data $\left(\mathrm{cm}^{-1}\right)$ of $\mathrm{H}_{2}$ pbzgh complexes.

\begin{tabular}{|c|c|c|c|c|c|c|c|}
\hline \multirow[b]{2}{*}{ Complex } & \multicolumn{3}{|c|}{ Amide } & \multirow[b]{2}{*}{$v(N-N)$} & \multirow{2}{*}{$\begin{array}{c}v(\mathrm{C}-\mathrm{O}) \\
\text { (phenolic) }\end{array}$} & \multirow{2}{*}{$\begin{aligned}>\mathbf{C}=\mathbf{N} \\
>\mathbf{C}=\mathbf{N}\end{aligned}$} & \multirow[b]{2}{*}{$v\left(\mathrm{NCO}^{-}\right)$} \\
\hline & $\mathbf{I}$ & II & III & & & & \\
\hline $\mathrm{H}_{2}$ platefh & 1730 & 1574 & 1375 & 933 & 1188 & 一 & - \\
\hline [Min(Hphagh/)] & 1670 & 1545 & 1395 & 975 & 1250 & 1602 & 1525,1381 \\
\hline [NG(Hplegh) $]$ & 1671 & 1548 & 1395 & 983 & 1263 & 1600 & 1521,1380 \\
\hline [Co(Hpleshlh] & 1675 & 1550 & 1402 & 985 & 1261 & 1610 & 1525,1378 \\
\hline [Cu(Hplozh) & 1600 & 1550 & 1406 & 984 & 1251 & 1612 & 1523,1370 \\
\hline [Zn(Hphreghl)] & 1678 & 1555 & 1390 & 982 & 1260 & 1608 & 1525,1383 \\
\hline
\end{tabular}

\section{Dxpinem}

\section{Stating materials}

Pyidoxal hydrochloride obtained from the Sigma Chem. Co., USA was used as received All the chemicals used were from BDH or E Merck. Pyridoxal $N$-benzoylghcyl hydrazone ( $\mathrm{H}_{2}$ pheagh) was prepared by mixing together cold aqueous solutions of pyidozal hydrochloride and $\mathbf{N}$-benzoylglycine hydrazide as reported earlier (Rao a d 1994. The crude product was recrystallised from hot methanol; Yield 82\%; m.p. $170{ }^{\circ} \mathrm{C}$. Found $\mathrm{C}, 5963 ; \mathrm{H}, 5-26 ; \mathrm{N}, 16-34 ; \mathrm{N}_{2} \mathrm{H}_{4}, 9-27 \% . \mathrm{C}_{17} \mathrm{H}_{18} \mathrm{O}_{4} \mathrm{~N}_{4}$ requires: $\mathrm{C}$, $5965 ; \mathrm{H}, 5-265 \mathrm{~N}, 16-37 ; \mathrm{N}_{2} \mathrm{H}_{4}, 9-35 \%$.

The ligand was further characterized on the basis of spectral data, viz. IR (table 1), NMR (table 2) and mass spectral data. In the mass spectrum of the ligand the base peak at $m / e=105$ comesponds to $\mathrm{C}_{6} \mathrm{H}_{5} \mathrm{CO}^{+}$. The molecular ion peak $\left(\mathrm{M}^{+}\right)$with $\mathrm{m} / \mathrm{e}=342$ appears with $\sim 100 \%$ intensity. The various fragments corresponding to the mass spectral peals of appreciable intensity are shown in figure 2.

The IR, NMR and mass spoctral data suggest the structure shown in figure 1 for $\mathrm{H}_{2}$ plageh

\section{Syuthesis and analysis of the complexes}

The complexes were prepared by stirring together aqueous methanol $(20: 80 \mathrm{v} / \mathrm{v})$ solutions of the appropriate metal acetate $(10 \mathrm{mmol} / 025 \mathrm{~g}$ in $10 \mathrm{ml}), \mathrm{H}_{2}$ pbzgh $(20 \mathrm{mmol} / 068 \mathrm{~g}$ in $30 \mathrm{ml})$ and aqueous $\mathrm{NaOH}(2.0 \mathrm{mmol} / 0.08 \mathrm{~g}$ in $20 \mathrm{ml})$ and adjusting, 
Table 2. ${ }^{1} \mathrm{H}$ and ${ }^{13} \mathrm{C}$ NMR spectral data* of $\mathrm{Zn}(\mathrm{II})$ complex of $\mathrm{H}_{2}$ pbzgh.

\begin{tabular}{|c|c|c|c|c|c|}
\hline $\begin{array}{l}\text { Protons/ } \\
\text { carbons }\end{array}$ & $\mathrm{H}_{2} \mathrm{pbzgh}$ & {$\left[\mathrm{Zn}(\mathrm{Hpbzgh})_{2}\right]$} & $\begin{array}{l}\text { Protons/ } \\
\text { carbons }\end{array}$ & $\mathrm{H}_{2}$ pbzgh & {$\left[\mathrm{Zn}(\mathrm{Hpbzgh})_{2}\right]$} \\
\hline 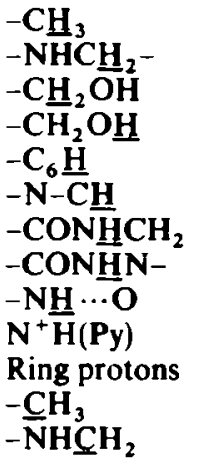 & $\begin{array}{c}2 \cdot 66 s \\
4.23 d \\
4.81 s \\
- \\
8 \cdot 20 s \\
8.59 d \\
8.78 t \\
9 \cdot 18 d \\
12.95 s \\
3 \cdot 19 s \\
7 \cdot 55,7.94(m) \\
14.36 \\
46.90\end{array}$ & $\begin{array}{c}2.55 s \\
4.09 d \\
4.63 s \\
5.31 s \\
7.96 s \\
8.53 d \\
8.77 t \\
9.07 b \\
12.36 s \\
3.29 b \\
7.59,7.96(\mathrm{~m}) \\
14.20 \\
45.27\end{array}$ & $\begin{array}{c}-\mathrm{CS}_{2} \mathrm{OH} \\
\mathrm{C}_{1} \\
\mathrm{C}_{2} \\
\mathrm{C}_{3} \\
\mathrm{C}_{4} \\
\mathrm{C}_{2} \\
\mathrm{C}_{3} \cdot \\
\mathrm{C}_{4} \\
\mathrm{C}_{5} . \\
\mathrm{C}_{6} \\
-\mathrm{NC} H \\
>\mathrm{CO}(\alpha) \\
>\mathrm{CO}\left(\alpha^{\prime}\right)\end{array}$ & $\begin{array}{r}58 \cdot 02 \\
131 \cdot 54 \\
128.34 \\
127 \cdot 40 \\
133 \cdot 54 \\
142 \cdot 38 \\
152 \cdot 84 \\
136 \cdot 72 \\
127.42 \\
136 \cdot 95 \\
142.90 \\
170.38 \\
166 \cdot 48\end{array}$ & $\begin{array}{r}60-35 \\
131 \cdot 36 \\
128 \cdot 25 \\
127 \cdot 36 \\
134 \cdot 47 \\
144 \cdot 81 \\
154 \cdot 88 \\
137 \cdot 57 \\
127 \cdot 36 \\
138-02 \\
150-89 \\
166-86 \\
166 \cdot 42\end{array}$ \\
\hline
\end{tabular}

* Proton spectral data are given in $\delta$ (w.r.t. TMS) and ${ }^{13} \mathrm{C}$ NMR data in ppm (w.r.t. DMSO-d 6 signal at $39 \cdot 50 \mathrm{ppm}) . s=$ singlet; $d=$ doublet; $t=$ triplet; $m=$ multiplet

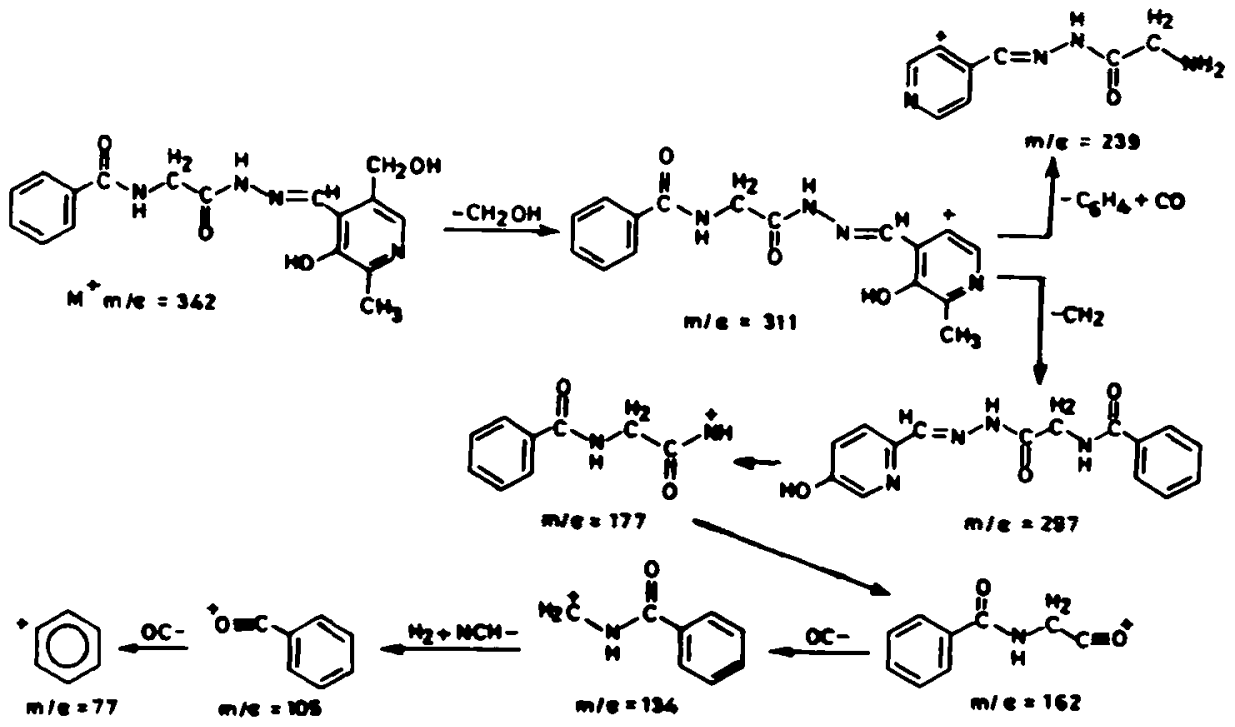

Figure 2. Mass spectral fragmentation pattern of pyridoxal $\mathrm{N}$-benzoylglycyl hydrazone $\left(\mathrm{H}_{2}\right.$ pbzgh).

if necessary, the $\mathrm{pH}$ of the solution to $\sim 7 \cdot 5$. The precipitated complexes were digested on a water bath for $\sim 1 \mathrm{~h}$, filtered, washed several times with aqueous methanol $(20: 80 \mathrm{v} / \mathrm{v})$ and dried at room temperature. The metal ions were determined after decomposing the organic matter with aqua regia followed by treatment with sulphuric acid, by using the standard literature procedure (Vogel 1971). Chloride was estimated 
gravimetrically as $\mathrm{AgCl}$. Hydrazine was determined volumetrically after subjecting the complexes to acid hydrolysis (Vogel 1971). Nitrogen was micro-analysed.

\subsection{Physical measurements}

Infrared spectra $\left(4000-400 \mathrm{~cm}^{-1}\right)$ of the complexes as $\mathrm{KBr}$ discs were recorded on a JASCO FT-IR model 5300 spectrometer and solid state (Nujol mull) electronic spectra on a Shimadzu-160A and a Cary-2390 UV-Vis-NIR spectrophotometers. The ${ }^{1} \mathrm{H}$ and ${ }^{13} \mathrm{C}$ NMR spectra were run on a JEOL FX-90Q multinuclear NMR spectrometer. Molar conductances were measured on a WTW conductivity meter. The room temperature magnetic susceptibility measurements were carried out on a CahnFaraday electrobalance using $\mathrm{Hg}\left[\mathrm{Co}(\mathrm{NCS})_{4}\right]$ as standard. The $\mathrm{C}, \mathrm{H}$ and $\mathrm{N}$ were microanalysed on a Perkin-Elmer $240 \mathrm{C}$ Analyser.

\section{Results and discussion}

The yields $(\%)$, melting temperatures, analytical data, $\mu_{\mathrm{eff}}$ values and the molar conductances of the complexes are given in table 3 . The analytical data reveal the formation of metal complexes corresponding to the general formula $\mathbf{M}(\mathbf{H p b z h})_{2}$. Thus, the organic ligand $\left(\mathrm{H}_{2} \mathrm{pbzgh}\right)$ may be shown to react with metal acetates as a uninegative ion in aqueous methanolic medium as represented by the following equation

$$
\begin{gathered}
\mathrm{M}\left(\mathrm{CH}_{3} \mathrm{COO}\right)_{2} \cdot n \mathrm{H}_{2} \mathrm{O}+2 \mathrm{H}_{2} \mathrm{pbzgh}+2 \mathrm{NaOH} \frac{\text { sirr, MeOH }- \text { water. dizes }\left(-70^{\circ}\right)}{\mathrm{pH}-7 \cdot 5} \\
\mathrm{M}(\mathrm{Hpbzgh})_{2}+2 \mathrm{CH}_{3} \mathrm{COONa}+(n+2) \mathrm{H}_{2} \mathrm{O}
\end{gathered}
$$

It is interesting to note that the isolation of the complexes was $p \mathrm{H}$-specific in the sense that they formed insoluble precipitates at $p \mathrm{H} \sim 7.4-7.6$ while any variation of $p \mathrm{H}$ above and below the range rendered the complexes soluable leading to clear homogeneous solutions. Pyridoxal $N$-benzoylglycyl hydrazone, like any other Schiff-base, is capable of coordinating in its protonated and/or deprotonated forms. A comparative account of the coordinating behaviour of this organic ligand with trivalent lanthanides (Rao et al 1994) vis-a-vis bivalent $3 d$-metal ions (present work) indicates that, in the former case, the ligand coordinates in its protonated as well as di-deprotonated forms giving rise to the formation of adducts and deprotonated complexes of the formulae $\left[\mathrm{Ln}\left(\mathrm{H}_{2} \mathrm{pbzgh}\right)_{2} \mathrm{Cl}_{2}\right] \mathrm{Cl}_{1} 4 \mathrm{H}_{2} \mathrm{O}$ and $\mathrm{Na}\left[\mathrm{Ln}(\mathrm{pbzgh})_{2}\left(\mathrm{H}_{2} \mathrm{O}\right)\right]$, while in the latter case it bonds through its mono-deprotonated form giving rise to the formation of deprotonated complexes of the type $\left[\mathrm{M}(\mathrm{Hpbzgh})_{2}\right]$. Even under rigorous experimental conditions, the ligand failed to give rise to formation of adduct complexes with the $3 d$-metal ions. All the present complexes are insoluble in common organic solvents but are soluble in coordinating solvents such as pyridine, DMSO and DMF. All the complexes are stable at room temperature but are decomposed on heating upto $300^{\circ} \mathrm{C}$. They are non-electrolytes in $10^{-3}$ M DMF solutions (Geary 1971) (table 3).

\subsection{Magnetic moments and electronic spectra}

The room temperature magnetic moments corrected for diamagnetism are given in table 3. The values of the $\mathrm{Cu}(\mathrm{II})$ and $\mathrm{Mn}$ (II) complexes correspond to one and five unpaired electrons respectively and give no specific information about their stereochemistry 


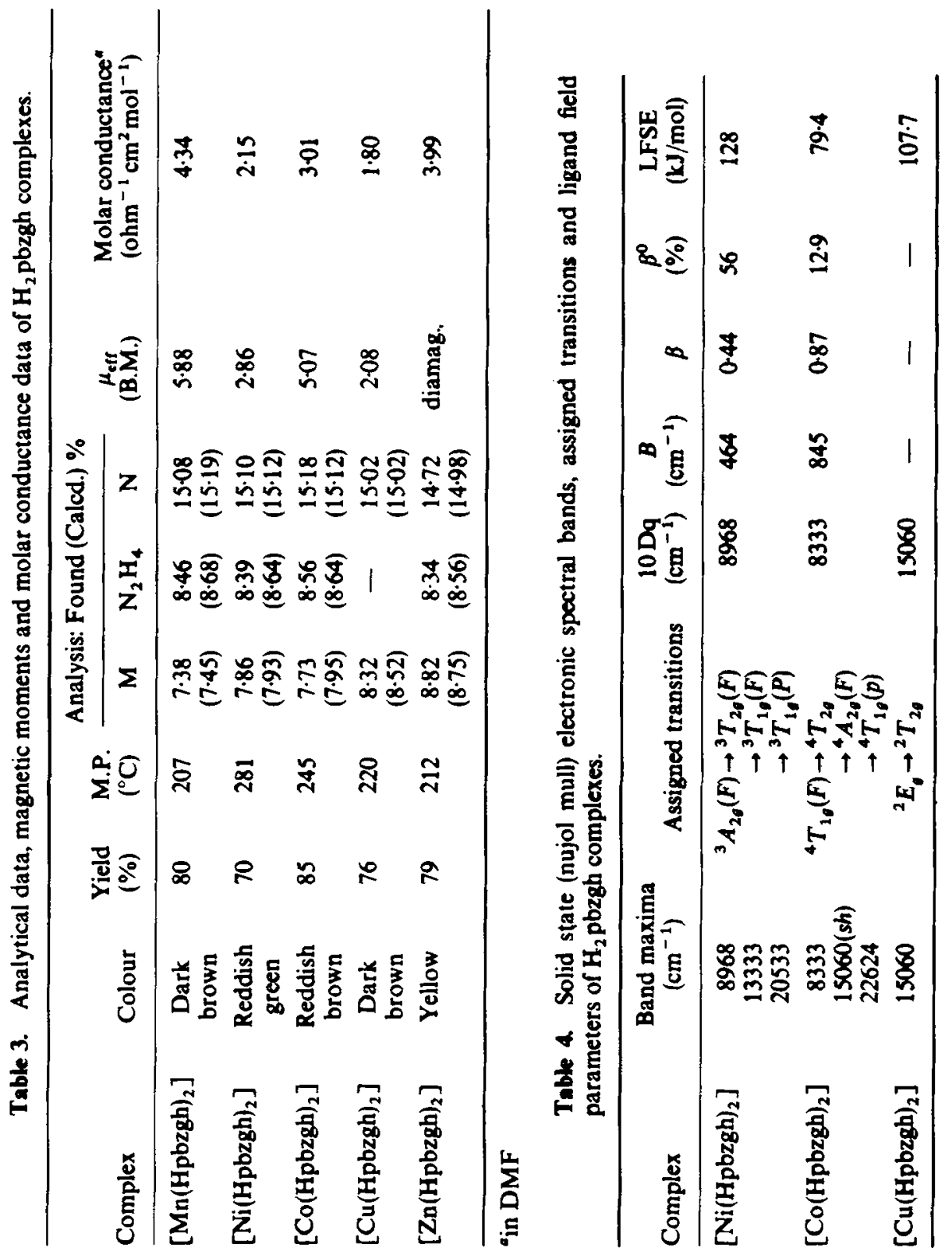


(Cotton and Wilkinson 1976) while those of the $\mathrm{Co}(\mathrm{II})$ and $\mathrm{Ni}(\mathrm{II})$ complexes are normal and suggest an octahedral stereochemistry around the metal ion (Figgis and Lewis 1964).

The solid state (Nujol mull) electronic spectrum of $\mathrm{H}_{2}$ pbzgh yields bands (at 248, 298,317 and $380 \mathrm{~nm}$ ) characteristic of the phenyl ring, $>\mathrm{C}=\mathrm{N},>\mathrm{C}=\mathrm{O}$ and phenolic chromophores. Complexation of the ligand with the metal ions shifts the phenolic group band position from the 380 to the $390-395 \mathrm{~nm}$ region which is indicative of the metal-ligand interaction through the phenolic chromophore. The electronic spectral (Nujol mull) bands of the $\mathrm{Co}(\mathrm{II}), \mathrm{Ni}(\mathrm{II})$ and $\mathrm{Cu}$ (II) complexes are listed in table 4 along with their assignments and the calculated parameters. The data are consistent with an octahedral/distorted octahedral geometry of the complexes (Neimann and Kivelson 1961; Lever 1968). The $d-d$ band in the $\mathrm{Cu}$ (II) complex is considerably blue-shifted when compared with the first band maximum of the corresponding Ni(II) complex indicating Jahn-Teller distortion of the ${ }^{2} E_{q}$ state in the former complex and the ratio of the above two-band positions works out to 1.29 which corresponds to an appreciable distortion (Jørgensen 1955).

\subsection{Infrared spectra}

The IR spectra of all the complexes have shown some band shifts which indicate the coordination mode of the ligand. In particular, there are some characteristic vibrations of the coordinated ligand in the enol form that are much more diagnostic of the formation of neutral complexes (table 1).

A comparison of the spectra of $\mathrm{H}_{2}$ pbzgh and the present complexes with respect to some diagnostic bands indicates that the broad band in the latter spectra centred at $\sim 1641 \mathrm{~cm}^{-1}$ may be a composite band of the amide-I frequencies of both the benzamide and hydrazide moieties, which appears to be resolved into two different peaks coinciding with $\sim 1675 \mathrm{~cm}^{-1}$ and $\sim 1625 \mathrm{~cm}^{-1}$ positions. Thus, the amide-I band of the hydrazide moiety undergoes a bathochromic shift $\left(v=55 \mathrm{~cm}^{-1}\right)$ while that of the benzamide moiety remains unaltered upon complex formation. Likewise, the spectra indicate bathochromic and hypsochromic shifts of the amide-II and amide-III frequencies respectively of only the hydrazide moiety indicating coordination to the metal ion through only the hydrazidic carbonyl group. A noteworthy point with respect to the present complexes is that the spectra, besides showing the amide-I, -II and amide-III bands of the hydrazidic carbonyl group, also show new bands characteristic of $>\mathrm{C}=\mathrm{N}-\mathrm{N}=\mathrm{C}<$ and $v\left(\mathrm{NCO}^{-}\right.$) chromophores (El-Sayed and Iskander 1971; Rao 1963). While the former bands imply coordination through the hydrazidic carbonyl group, the latter bands indicate amide $\rightleftharpoons$ imidol tautomerism in the hydrazide moiety and subsequent loss of the imidolic proton. These contradicting features may be amicably explained by assuming simultaneous coordination of one $\mathrm{Hpbzgh}^{-}$species through its amide (thereby retaining all the amide bands) and of another species through its imidolic oxygen (thereby resulting in the disappearance of the amide bands) within the same complex molecule. Coordination through one of the azomethine nitrogens is indicated by the hypsochromic shift of the $v(\mathrm{~N}-\mathrm{N})$ band $\left(\mathrm{H}_{2} \mathrm{pbzgh}\right.$, $933 \mathrm{~cm}^{-1}$, complexes, $\sim 975 \mathrm{~cm}^{-1}$ ) (Braibanti et al 1968). Interaction with the $\mathrm{M}^{2+}$ through the phenolate oxygen in all the present complexes may be invoked on the basis of the hypsochromic shift of the $v(\mathrm{C}-\mathrm{O})_{\text {phenolic }}$ mode (Inomata et al 1974), $\left(\mathrm{H}_{2} \mathrm{pbzgh}\right.$, $1188 \mathrm{~cm}^{-1}$; complexes, $1260-1252 \mathrm{~cm}^{-1}$ ). With regard to the pyridoxal moiety, support towards retention of the zwitterion upon complexation may be invoked by the 
appearance of low-intensity broad bands at $\sim 2033 \mathrm{~cm}^{-1}$ and $\sim 2552 \mathrm{~cm}^{-1}$. The discussion on NMR spectra, however, corroborates the presence of pyridoxal moieties with and without a hemi-acetal bridge in the $\left[\mathrm{M}(\mathrm{Hpbzgh})_{2}\right]$ molecule.

\section{$3.3{ }^{1} \mathrm{H}$ and ${ }^{13} \mathrm{C} N \mathrm{NM}$ spectra}

The ${ }^{1} \mathrm{H}$ and ${ }^{13} \mathrm{C}$ NMR spectra of $\mathrm{H}_{2}$ pbzgh and $\mathrm{Zn}$ (II) complex were recorded in DMSO- $d_{6}$ solutions and the spectral data along with the assignments are given in table 2. The assignments of the ${ }^{13} \mathrm{C}$ NMR spectra have been made applying the principle of substituent additivity (Silverstein et al 1981). The numbering of the carbon atoms is as shown in figure 1.

The ${ }^{1} \mathrm{H}$ and ${ }^{13} \mathrm{C}$ NMR spectra of the $\mathrm{Zn}$ (II) complex shows chemical shifts for hydrazidic $-\mathrm{NH},-\mathrm{N}=\mathrm{CH} /-\mathrm{N}-\mathrm{CH},>\underline{\mathrm{C}}=\mathrm{O} />\underline{\mathrm{C}}-\mathrm{O}$ of the hydrazidic moiety, $-\mathrm{N}=\underline{\mathrm{C}} \mathrm{H}-\mathrm{N}-\underline{\mathrm{C}} \mathrm{H}, \mathrm{C}_{2}$, and $\mathrm{C}_{4}$, protons and carbons respectively. An important feature is that the integration of the signal due to $>\mathrm{CO}-\mathrm{NH}(907 \delta)$ corresponds to approximately one proton. This can be explained in terms of deprotonation of one ( $>\mathrm{C}=\mathrm{ONH}$ ) proton via amide $\rightleftharpoons$ imidol tautomerism. The observation is, however, in good agreement with the IR data where two different bands are observed for each of the protonated and deprotonated hydrazidic $>\mathrm{C}=\mathrm{O}$ moieties (vide table 1). Further, the appearance of signals due to $\mathrm{CH}_{2} \mathrm{OH}(5 \cdot 30 \delta)$, pyridinium proton $(3.20 \delta)$ and $-\mathrm{N}-$ $\underline{\mathrm{H}} \cdots \mathrm{O}^{-}(12.95 \delta)$ protons imply the existence of two ligands with and without hemi-acetal (zwitterion) forms. The considerable shifts in ${ }^{1} \mathrm{H}$ and ${ }^{13} \mathrm{C}$ signals for hydrazidic carbonyl oxygen, azomethine nitrogen and phenolate oxygen suggest the tridentate nature of the $\mathrm{H}_{2}$ pbzgh.

\section{Conclusions}

Pyridoxal $\mathrm{N}$-benzoylglycyl hydrazone $\left(\mathrm{H}_{2} \mathrm{pbzgh}\right)$ forms transition metal complexes of the type $\mathbf{M}\left(\mathrm{Hpbzgh}_{2}\right.$ with octahedral/distorted octahedral geometry (figure 3). Spectral data indicate coordination of the mono-deprotonated ligand through hydrazidic carbonyl/imidol oxygen, azomethine nitrogen and phenolate oxygen. Pyridoxal moiety of the coordinated ligands is believed to contain zwitterions in both normal

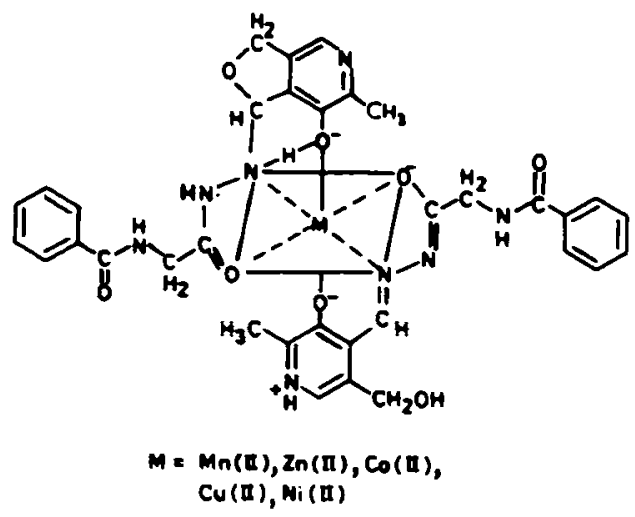

Figure 3. Proposed structure for the $3 d$-metal complexes of $\mathbf{H}_{2}$ pbzgh. 
and hemi-acetal forms in the metal complexes as suggested by FT-IR and NMR spectral data.

\section{Acknowledgements}

The authors are thankful to Prof. R C Srivastava for encouragement. Recording of mass spectrum at Regional Sophisticated Instrumentation Centre, Central Drug Research Institute, Lucknow, is gratefully acknowledged.

\section{References}

Bada J L and Scholeder R A 1975 Naturwiss 6271

Braibanti A, Dallavalle F, Pellinghelli M A and Laporati E 1968 Inorg. Chem. 71430

Cotton F A and Wilkinson G 1976 Advanced inorganic chemistry (New Delhi: Wiley Eastern)

Casella L, Gullotti M and Pacchioni G $1982 \mathrm{~J}$. Am. Chem. Soc. 1042386

Dunathan H C 1963 Chemical and biological aspects of pyridoxal catalysis (Interscience: New York)

Dunathan H C 1971 Adv. Enzymol. 3579

El-Sayed L and Iskander M F 1971 J. Inorg. Nucl. Chem. 33107

Friedman M and Gumbamann M R 1984 J. Nutr. 1142089

Figgis B N and Lewis J 1964 Prog. Inorg. Chem. 697

Geary W J 1971 Coord. Chem. Rev. 781

Inomata Y, Inomata T and Morikawi T 1974 Bull. Chem. Soc. Jpn. 47818

Jørgensen C K 1955 Acta Chim. Scand. 91362

Kovaes J 1980 In The peptides: Analysis, synthesis and biology (New York: Academic Press) vol. 2, pp. 486-567

Lever A B P 1968 Inorganic electronic spectroscopy (Amsterdam: Elsevier)

Metzler C M, Cabill A and Metzler D E $1980 \mathrm{~J}$. Am. Chem. Soc. 1026075

Neimann R and Kivelson D 1961 J. Chem. Phys. 35149

Rao C N R 1963 Chemical applications of infrared spectroscopy (New York: Academic Press) p. 265

Rao T R, Sahay M and Aggarwal R C 1985a Synth. React. Inorg. Met.-Org. Chem. 15 175, 209

Rao T R, Sahay M and Aggarwal R C 1985b Proc. Indian Acad. Sci. (Chem. Sci.) 95525

Rao T R, Sahay M and Aggarwal R C 1985c Indian J. Chem. A24 79, 244, 649

Rao T R and Singh G 1989 Transition Met. Chem. 14471

Rao T R and Singh G 1991 Spectrochim. Acta A47 727

Rao T R, Singh G and Khan I A 1989 Transition Met. Chem. 1415

Rao T R, Singh G and Kumar P A 1994 J. Chem. Res. (M) 861

Rao T R, Singh G, Sastry P S S J and Lonibala R K 1992 Synth. React. Inorg. Met.-Org. Chem. 221041

Rao T R and Srivastava M R 1992 Bull. Chem. Soc. Jpn. 652766

Shanbag V M and Martell A E 1980 Inorg. Chem. 291023

Silverstein R M, Bassler G C and Morrill T C 1981 Spectroscopic identification of organic compounds 4th edn (New York: John Wiley \& Sons) p. 264

Smith G G, Williams K M and Wonnacott D M 1978 J. Org. Chem. 431

Vogel A I 1971 A test-book of quantitative inorganic analysis (London: ELBS \& Longmans) 